\title{
A new insight into the definition of microcephaly in Zika congenital syndrome era
}

\section{Uma nova visão da definição de microcefalia na era da síndrome congênita do vírus Zika}

\author{
Una nueva perspectiva en la definición de \\ microcefalia durante la era del síndrome \\ congénito Zika
}

Fabiana Cristina Lima da Silva Pastich Gonçalves 1 Marília de Carvalho Lima 2

Ricardo Arraes de Alencar Ximenes 3

Demócrito de Barros Miranda-Filho 4

Celina Maria Turchi Martelli 5

Laura Cunha Rodrigues 6

Wayner Vieira de Souza 7

Pedro Israel Cabral de Lira 2

Sophie Helena Eickmann 2

Thalia Velho Barreto Araújo 1

doi: 10.1590/0102-311X00228520

\begin{abstract}
This study aimed to compare the anthropometric measurements and body proportionalities of neonates born before the Zika virus epidemic with those born during this period. We compared 958 neonates born during the pre-Zika epidemic with 264 neonates born during the epidemic period. The newborns had their head circumference, weight, and length classified according to the Fenton \& Kim growth chart. We considered disproportionate those individuals that presented microcephaly and adequate weight or length for sex and gestational age, and those whose head circumferences were lower than the ratio $(($ length / 2 $)+9.5)-2.5 \mathrm{~cm}$. We estimated the frequencies of Zika positivity and brain imaging findings among neonates with microcephaly born during the epidemic period, concerning the anthropometric and body proportionality parameters. Low weight and proportionate microcephaly were similar among newborns from both periods. However, the frequencies of newborns with microcephaly with a very low length and disproportionate microcephaly were higher among the neonates of the epidemic period with brain abnormalities and positive for Zika virus. We conclude that, at birth, the disproportion between head circumference and length can be an indicator of the severity of microcephaly caused by congenital Zika.
\end{abstract}

Microcephaly; Congenital Zika Syndrome; Birth Weight

\section{Correspondence}

F. C. L. S. P. Gonçalves

Universidade Federal de Pernambuco.

Av. Prof. Moraes Rego 1235, Recife, PE 50670-901, Brasil.

fabiana.clsilva@ufpe.br

1 Universidade Federal de Pernambuco, Recife, Brasil.

2 Centro de Ciências da Saúde, Universidade Federal de

Pernambuco, Recife, Brasil.

${ }^{3}$ Hospital das Clínicas, Universidade Federal de Pernambuco, Recife, Brasil.

4 Universidade de Pernambuco, Recife, Brasil.

5 Instituto de Patologia Tropical e Saúde Publica, Universidade Federal de Goiás, Goiânia, Brasil.

${ }^{6}$ London School of Hygiene and Tropical Medicine, University of London, London, U.K.

7 Instituto Aggeu Magalhães, Fundação Oswaldo Cruz, Recife, Brasil. 


\section{Introduction}

Microcephaly is one of the manifestations of congenital Zika syndrome 1,2,3 and is generally considered a significant anthropometric parameter for the screening of congenital Zika virus infection 4. However, we also observed that this indicator occurs in neonates not exposed to congenital infections and it is considered a more frequent condition in neonates with low weight and length at birth 5 , situations considered a proxy for intrauterine growth restriction 6 .

One way to investigate microcephaly is based on its relation to the proportionality between the anthropometric parameters, weight and length ${ }^{7}$. In the protocol for monitoring changes in the growth and development of neonates exposed to Zika virus infection, the Brazilian Ministry of Health ${ }^{4}$ proposes that proportionate microcephaly may indicate that the child is overall small without an associated pathological condition; sometimes, the body disproportionality is used as a criterion for the definition of microcephaly 8 . However, when considering body proportionality as a normal parameter of intrauterine growth, the problem lies on the fact that congenital Zika virus infection is associated with intrauterine growth restriction ${ }^{9}$; thus, there could be a global impairment of head circumference, weight, and length.

Dine et al. 10 suggest a relation between the head circumference and length in the first year of life. Investigating the proportion between head circumference and other anthropometric parameters in neonates, who were infected in uterus by Zika virus, is important to better understand microcephaly by congenital infection, its relationship to body proportionality, severity, and its diagnosis in neonates with low weight and length 11 . Therefore, this study aims to investigate and to compare the relationships between head circumference, weight, length, and body proportionality at birth in a group of neonates born before the Zika virus epidemic and a group of neonates born during the Zika virus infection-associated microcephaly epidemic.

\section{Methods}

\section{Study design and population}

This study compared the head circumferences and the adequacy of this measurement to other anthropometric parameters between two groups of neonates. These groups were born in two distinct periods, in 2016, during the Zika virus-related microcephaly epidemic and in 1992, from a research of a historical group of infants assembled from well-defined birth cohort study in the state of Pernambuco, Brazil.

The first group was composed of 264 newborns who participated in the case-control study that investigated intrauterine exposure to Zika virus as a risk factor for microcephaly. These neonates were born during the microcephaly epidemic, between January and November 2016 (91 cases and 173 controls), in eight public maternity hospitals and resided in Pernambuco 1 . The historical control group consists of 958 women of lower socioeconomic status who were enrolled in a retrospective cohort of pregnant women, recruited between April and December 1992, in the two public maternity hospitals in the municipality of Palmares (Pernambuco). The aforementioned study aimed to evaluate the effect of maternal physical labor during pregnancy on neonates' size at birth 12 .

\section{Case-control study}

In the case-control study, the recruitment based on matching criteria was described by Araújo et al. 1 . Gestational age was assessed by fetal ultrasonography in the first or second trimester of pregnancy, and, in cases where these data were not available, the gestational age was determined based on the date of the last menstruation period recorded on the antenatal care card or self-reported by the woman. When both information were unavailable, the method of Capurro et al. ${ }^{13}$ was used.

The head circumference was measured in the delivery room with non-flexible Teflon tape and was re-evaluated from 12 to 24 hours after delivery by a neonatologist who participated in the study 1 . Weight and length were measured at birth following the hospital's routine procedures, 
however, for stillbirths, this information was retrieved from the records of the pathology team who performed the autopsy. These anthropometric data were classified using the Fenton \& Kim growth chart 14. Cases of anencephaly or encephalocele were excluded. Controls were newborns without microcephaly, brain abnormalities on transfontanelle ultrasonography, and without congenital defects detected via physical examination by the study neonatologist. Cases were examined with non-contrast computed tomography (CT scan). Laboratory confirmation of Zika virus infection was defined in newborns who had qRT-PCR and/or IgM positive for Zika virus in some biological specimen (serum, cerebrospinal fluid [CSF] or macerated tissues obtained by necropsy in the case of stillbirths) 1 .

\section{Historical cohort study}

In the cohort of pregnant women, newborns were recruited in the first 24 hours of life. During this period anthropometric measurements of weight, length and head circumference were taken by a neonatologist, the principal investigator, using standardized procedure 12 . The head circumference was measured with non-flexible Teflon tape. The method of Capurro et al. 13 was applied to estimate gestational age at birth.

Pregnant women who had preeclampsia, twin pregnancy, and newborns with congenital infection, chromosomal abnormalities or other malformations were excluded from the study. Further information on socioeconomic and demographic conditions, exposure to smoking, gestational conditions and information on the anthropometric measurements were described by Lima et al. 12 .

For this analysis, the anthropometric data for head circumference, weight, and length were classified using the Fenton \& Kim growth chart 14.

In both studies, newborns or stillbirths with head circumference at least two standard deviations below the mean for gestational age and sex, according to the Fenton \& Kim growth chart 14, were defined as microcephaly.

\section{Study variables}

To characterize anthropometric patterns and body proportionalities of these two samples of neonates, the weight, length, head circumference, gestational age, and sex were considered. A case with undefined sex was considered female for microcephaly classification and analysis.

At birth, neonates were classified as appropriate weight (greater than or equal to 2,500g), low weight (from 1,500g to 2,499g) or very low weight (less than 1,500g). For analysis, the last two categories were combined into a single category.

We defined low weight and low length for gestational age as, at least, two standard deviations below the mean for gestational age and sex, respectively, according to the Fenton \& Kim growth chart 14. Anthropometric data were also evaluated according to the Intergrowth 15 and World Health Organization (WHO) curves 16, and this corroborates with the Fenton \& Kim growth chart results. Gestational age was categorized as full-term when above or equal to 37 gestational weeks and preterm when below 37 gestational weeks.

Microcephaly was defined as proportionate microcephaly when weight and length were less than two standard deviations below the mean for gestational age and sex, and disproportionate microcephaly when weight and/or length were above or equal to two standard deviations for the mean for gestational age and sex ${ }^{7}$.

Furthermore, to assess the head proportion we used the equation proposed by Dine et al. 10, who consider a normal pattern of head circumference when this is equal to the ratio ((length / 2) + 9.5) $\pm 2.5 \mathrm{~cm}$. We defined as disproportionate microcephaly when newborns with microcephaly had the head circumference less than the ratio ((length / 2) +9.5$)-2.5 \mathrm{~cm}$ and proportional microcephaly when the head circumference was equal or greater than the ratio value.

In the neonates with microcephaly identified in the case-control study, we analyzed the relationship between body proportionality, anthropometric parameters, and head circumference, stratified by laboratory confirmation of Zika virus infection and by the presence of abnormalities at brain imaging. 
Data were analyzed using SPSS software, version 15 (https://www.ibm.com/). The frequency distribution among the variables was evaluated, and the normality of the distribution and the homogeneity of the variances (Bartlett's test) were assessed for comparison of the anthropometric measurements. When these assumptions for the comparison of means with the t-test were not met, the non-parametric equivalent, Mann-Whitney U test, was performed. Pearson's chi-square test was used to compare the frequencies of the variables, and Fisher's exact test was employed when necessary. Values of $\mathrm{p} \leq$ 0.05 were considered significant.

\section{Ethical aspects}

The study was conducted according to the Declaration of Helsinki, and all procedures involving humans were approved by the Ethics Research Committee of the Aggeu Magalhães Institute, Oswaldo Cruz Foundation (Fiocruz Pernambuco) and by the Ethics Research Committee of the Pan American Health Organization (PAHO).

\section{Results}

Among the 958 neonates evaluated in the period prior to the introduction of the Zika virus in Pernambuco, $51 \%$ were male and $8 \%$ had weight lower than 2,500g. The frequencies of low weight and low length for gestational age at birth were 6\% (57 neonates) and 7\% (64 neonates), respectively. We observed microcephaly in $2.6 \%$ of the sample and all of those affected were born at full-term. Most neonates with microcephaly had weight below 2,500g, and low weight and length for gestational age at birth. Weight and length of less than minus three standard deviations were also more frequent among neonates with microcephaly (Table 1).

Among the newborns with microcephaly from the epidemic period, most (77\%) had a weight lower than 2,500g, low weight, and low length for gestational age at birth, and $28 \%$ were premature. The proportions of neonates with weight and length at birth less than three standard deviations below the mean to sex and gestational age were $25 \%$. Among the newborns of the control group of the casecontrol study, $51 \%$ were male, $8 \%$ were under 2,500g, $1 \%$ had low birth weight, and $5 \%$ had low birth length (Table 2).

Table 3 shows the ratios of low weight, low length, and body proportionality at birth in newborns with microcephaly from the epidemic and pre-epidemic periods. In the epidemic period, we observed an increase in the numbers of neonates with microcephaly weighing less than $2.500 \mathrm{~g}$, with length at least three standard deviations below the mean and disproportionate according to the criterion of Dine et al. 10 .

Table 4 shows the comparison of the mean values for weight, length, and head circumference at birth, measured in the original and z-score scales, between newborns with microcephaly from the pre-epidemic and epidemic periods. These anthropometric measurements were significantly smaller in the group of neonates with microcephaly born during the epidemic period, however only the head circumference of this group remained significantly lower $(p=0.041)$ when they were controlled for the gestational age ( $\mathrm{z}$-score), whereas length showed a borderline significant difference $(\mathrm{p}=0.056)$.

Table 5 presents the results of brain imaging (CT scan) examinations of the newborns with microcephaly born during the epidemic period according to the anthropometric and body proportionality parameters. According to the criterion of Dine et al. 10, we observed a $47 \%$ higher frequency of disproportionate microcephaly among neonates with brain imaging abnormalities compared to those with normal brain imaging. According to the same criteria, $67 \%$ of the newborns with proportionate microcephaly presented abnormalities brain imaging. 
Table 1

Head circumference at birth of neonates from the historical cohort control. State of Pernambuco, Brazil (1992).

\begin{tabular}{|c|c|c|c|c|c|c|}
\hline \multirow[t]{3}{*}{ Characteristics } & \multicolumn{5}{|c|}{ Head circumference for gestational age and sex } & \multirow[t]{3}{*}{ p-value } \\
\hline & \multirow[t]{2}{*}{$N=958$} & \multicolumn{2}{|c|}{$<-2$ SD } & \multicolumn{2}{|c|}{$\geq-2$ SD } & \\
\hline & & $N=25$ & $\%$ & $N=933$ & $\%$ & \\
\hline \multicolumn{7}{|l|}{ Sex } \\
\hline Male & 485 & 9 & 36.0 & 476 & 51.0 & 0.100 \\
\hline Female & 473 & 16 & 64.0 & 457 & 49.0 & \\
\hline \multicolumn{7}{|c|}{ Gestational age at birth } \\
\hline Pre-term & 43 & 0 & 0.0 & 43 & 4.6 & 0.313 \\
\hline Full term & 915 & 25 & 100.0 & 890 & 95.4 & \\
\hline \multicolumn{7}{|l|}{ Birth weight (g) } \\
\hline$<1,500$ & 0 & 0 & 0.0 & 0 & 0.0 & $<0.001$ \\
\hline $1,500-2,499$ & 76 & 12 & 48.0 & 64 & 6.9 & \\
\hline$\geq 2,500$ & 882 & 13 & 52.0 & 869 & 93.1 & \\
\hline \multicolumn{7}{|c|}{ Birth weight/Gestational age (SD) } \\
\hline$<-2$ & 57 & 16 & 64.0 & 41 & 4.4 & $<0.001$ \\
\hline$\geq-2$ & 901 & 9 & 36.0 & 892 & 95.6 & \\
\hline \multicolumn{7}{|c|}{ Birth weight/Gestational age (SD) } \\
\hline$<-3$ & 7 & 4 & 16.0 & 3 & 0.0 & $<0.001$ \\
\hline$\geq-3$ & 951 & 21 & 84.0 & 930 & 100.0 & \\
\hline \multicolumn{7}{|c|}{ Length at birth/Gestational age (SD) } \\
\hline$<-2$ & 64 & 16 & 64.0 & 48 & 5.1 & $<0.001$ \\
\hline$\geq-2$ & 894 & 9 & 36.0 & 885 & 94.8 & \\
\hline \multicolumn{7}{|c|}{ Length at birth/Gestational age (SD) } \\
\hline$<-3$ & 3 & 2 & 8.0 & 1 & 0.0 & 0.002 \\
\hline$\geq-3$ & 955 & 23 & 92.0 & 932 & 100.0 & \\
\hline
\end{tabular}

SD: standard deviation.

Note: proportion of neonates with microcephaly in the cohort $(25 / 958=2.6 \%)$.

Table 6 shows the relationship between the laboratory evidence of Zika virus positivity and the anthropometric and proportionality parameters of the cases of microcephaly during the epidemic period. According to the Dine et al. 10, the frequency of disproportionate neonates criterion was 2.6 folds higher (31\%) among those with laboratory confirmation of Zika virus infection when compared to neonates with negative laboratory results. Whereas among proportionate newborns with microcephaly, 69\% were positive for the Zika virus.

\section{Discussion}

Our study indicates that microcephaly is more severe in neonates born during the epidemic period. Neonates with microcephaly and laboratory confirmation of congenital Zika virus infection or brain damage presented greater frequency of body disproportionality of the head circumference relative to length. In contrast, the parameters weight for gestational age and proportionality between weight, length, and head circumference were similar among the groups of neonates with microcephaly born before the Zika virus epidemic and those born during the epidemic.

We associated microcephaly with lower weight and length among the neonates born before the epidemic period. Born small-for-gestational age is considered a proxy for intrauterine growth restriction 6 . In this group of neonates, the lowest weight, head circumference and length may be related to 
Table 2

Head circumference at birth of neonates from the epidemic period of microcephaly due to Zika virus. State of Pernambuco, Brazil (2016).

\begin{tabular}{|c|c|c|c|c|c|c|}
\hline \multirow[t]{3}{*}{ Characteristics } & \multicolumn{5}{|c|}{ Head circumference for gestational age and sex } & \multirow[t]{3}{*}{ p-value } \\
\hline & \multirow[t]{2}{*}{$N=264$} & \multicolumn{2}{|c|}{$<-2$ SD (case) } & \multicolumn{2}{|c|}{$\geq-2$ SD (control) } & \\
\hline & & $N=91$ & $\%$ & $N=173$ & $\%$ & \\
\hline \multicolumn{7}{|l|}{ Sex } \\
\hline Male & 118 & 29 & 31.9 & 89 & 51.4 & $<0.001$ \\
\hline Female & 145 & 61 & 67.0 & 84 & 48.6 & \\
\hline Intersex & 1 & 1 & 0.1 & 0 & 0.0 & \\
\hline \multicolumn{7}{|c|}{ Gestational age at birth } \\
\hline Pre-term & 45 & 25 & 27.5 & 20 & 11.6 & 0.001 \\
\hline Full term & 219 & 66 & 72.5 & 153 & 88.4 & \\
\hline \multicolumn{7}{|l|}{ Birth weight (g) } \\
\hline$<1,500$ & 18 & 18 & 19.8 & 0 & 0.0 & $<0.001$ \\
\hline $1,500-2,499$ & 66 & 52 & 57.4 & 14 & 8.1 & \\
\hline$\geq 2,500$ & 180 & 21 & 23.1 & 159 & 91.9 & \\
\hline \multicolumn{7}{|c|}{ Birth weight/Gestational age (SD) } \\
\hline$<-2$ & 63 & 61 & 67.0 & 2 & 1.2 & $<0.001$ \\
\hline$\geq-2$ & 201 & 30 & 33.0 & 171 & 98.8 & \\
\hline \multicolumn{7}{|c|}{ Birth weight/Gestational age (SD) } \\
\hline$<-3$ & 23 & 23 & 25.3 & 0 & 0.0 & $<0.001$ \\
\hline$\geq-3$ & 241 & 68 & 74.7 & 173 & 100.0 & \\
\hline \multicolumn{7}{|c|}{ Length at birth/Gestational age * (SD) } \\
\hline$<-2$ & 70 & 61 & 67.0 & 9 & 5.2 & $<0.001$ \\
\hline$\geq-2$ & 192 & 29 & 33.0 & 163 & 94.8 & \\
\hline \multicolumn{7}{|c|}{ Length at birth/Gestational age * (SD) } \\
\hline$<-3$ & 26 & 23 & 25.4 & 3 & 1.7 & $<0.001$ \\
\hline$\geq-3$ & 236 & 67 & 73.6 & 169 & 98.2 & \\
\hline
\end{tabular}

SD: standard deviation.

* $N=262$

the fetal growth restriction common in neonates from regions of extreme poverty 12,17 , such as the rural areas of Pernambuco.

The frequency of low weight and length for gestational age at birth was also high among neonates born with microcephaly during the Zika virus epidemic period, which suggests fetal growth restriction among that neonates, as evidenced by Brasil et al. 9. However, although Zika virus causes intrauterine growth restriction, the distribution of body weight and proportionality was similar in neonates born with microcephaly during the pre-epidemic and epidemic periods, even controlling for weight for gestational age and sex. On the other hand, the groups differed concerning the difference between length and head circumference, in which both were more compromised in the neonates with microcephaly from the epidemic period. These results are reinforced by the fact that extreme cases of low length were more frequent in neonates with microcephaly born during the epidemic period. Therefore, we emphasize that severe linear and head growth impairments were present in neonates with microcephaly born during the Zika virus epidemic period.

The possibility of studying children exposed or not to Zika virus allowed us to compare the body phenotypes of these neonates under different growth restriction conditions. Birth weight corrected for gestational age did not differ among neonates with microcephaly and possible exposure to Zika virus from those born before the virus epidemic, nor did it differ among children with positive laboratory results for Zika virus and the presence of altered brain image. In other words, the weight parameter is poorly specific for differentiating cases of microcephaly for different reasons. 
Table 3

Proportions of neonates with weight, length, and body proportionality at birth in neonates with microcephaly from the epidemic period and historical cohort control. State of Pernambuco, Brazil (1992 and 2016).

\begin{tabular}{|c|c|c|c|c|c|}
\hline \multirow[t]{3}{*}{ Anthropometric characteristic } & \multicolumn{4}{|c|}{ Newborns with microcephaly } & \multirow[t]{3}{*}{ p-value * } \\
\hline & \multicolumn{2}{|c|}{$\begin{array}{c}\text { Case-control } \\
\text { (epidemic period) }\end{array}$} & \multicolumn{2}{|c|}{$\begin{array}{c}\text { Cohort } \\
\text { (pre-epidemic period) }\end{array}$} & \\
\hline & $\mathbf{N}=91$ & $\%$ & $\mathbf{N}=\mathbf{2 5}$ & $\%$ & \\
\hline \multicolumn{6}{|l|}{ Birth weight (g) } \\
\hline$<2,500$ & 70 & 76.9 & 12 & 48.0 & 0.006 \\
\hline$\geq 2,500$ & 21 & 23.1 & 13 & 52.0 & \\
\hline \multicolumn{6}{|l|}{ Birth weight/Gestational age (SD) } \\
\hline$<-2$ & 61 & 67.0 & 16 & 64.0 & 0.480 \\
\hline$\geq-2$ & 30 & 33.0 & 9 & 36.0 & \\
\hline \multicolumn{6}{|c|}{ Length at birth $* \star /$ Gestational age (SD) } \\
\hline$<-2$ & 61 & 67.0 & 16 & 64.0 & 0.450 \\
\hline$\geq-2$ & 29 & 32.0 & 9 & 36.0 & \\
\hline \multicolumn{6}{|l|}{ Birth weight/Gestational age (SD) } \\
\hline$<-3$ & 23 & 25.3 & 4 & 16.0 & 0.245 \\
\hline$\geq-3$ & 68 & 74.7 & 21 & 84.0 & \\
\hline \multicolumn{6}{|c|}{ Length at birth **/Gestational age (SD) } \\
\hline$<-3$ & 23 & 25.3 & 2 & 8.0 & 0.047 \\
\hline$\geq-3$ & 67 & 73.6 & 23 & 92.0 & \\
\hline \multicolumn{6}{|l|}{ Body proportionality (z-score) } \\
\hline Disproportionate & 50 & 55.6 & 14 & 56.0 & 0.580 \\
\hline Proportionate & 40 & 44.4 & 11 & 44.0 & \\
\hline \multicolumn{6}{|l|}{ Body proportionality *** } \\
\hline Disproportionate & 17 & 18.9 & 1 & 4.0 & 0.057 \\
\hline Proportionate & 73 & 81.1 & 24 & 96.0 & \\
\hline
\end{tabular}

SD: standard deviation.

* Pearson's chi-square; Fisher's exact test;

** Length at birth was unavailable for 1 child $(n=90)$;

$\star \star \star$ Proportionality criterion according to Dine et al. 10.

The intrauterine environment is a determinant for fetal growth, and the regulation of this growth is mediated by maternal-placental-fetal factors 18. In situations of fetal growth restriction from noninfectious causes, the low supply of nutrients to the fetus leads to adaptation of the blood circulation, with blood being diverted from the venous ducts of the liver and with vasodilation of the middle brain artery of the fetus 19 , with the result of a prioritization of blood flow to supply nutrients and oxygen to tissues essential for survival, such as the brain 20. In the condition of fetal growth restriction, the first effect is impaired weight gain, followed by linear growth deficit and, lastly, the impairment of head circumference growth, considering that brain growth would be preserved at the expense of other organs, and that this growth deficit would occur in a progressive and directly proportional manner to the severity of the growth restriction 21.

However, in congenital Zika syndrome, we observed evidence of abnormal flow in the brain and in the arteries of the umbilical of fetus ${ }^{9}$, and brain damage 22 reflected by calcification in the subcortical area, cortical malformation, corpus callosum hypoplasia and decreased brain volume 23 . It can be assumed that brain damage directly influences the weight and length of these newborns since these parameters are strongly correlated ${ }^{10}$. At the same time, because the infection compromises specific areas of the brain, it is possible that it causes changes in the brain function and thereby affects the neuroendocrine regulation of growth. This impaired regulation, in turn, may be related to the severity of the injury and the compromise of the anthropometric parameters. 
Means of anthropometric parameters at birth, in raw and z-scores, between neonates with microcephaly in the epidemic period and historical cohort control. State of Pernambuco, Brazil (1992 and 2016).

\begin{tabular}{|c|c|c|c|c|}
\hline \multirow[t]{2}{*}{ Anthropometric characteristics } & \multicolumn{4}{|c|}{ Neonates with microcephaly } \\
\hline & $N=116$ & Mean & SD & p-value * \\
\hline \multicolumn{5}{|l|}{ Birth weight (g) } \\
\hline Epidemic period (case-control) & 91 & $2,045.75$ & 629.05 & 0.001 \\
\hline Pre-epidemic period (cohort) & 25 & $2,500.40$ & 365.83 & \\
\hline \multicolumn{5}{|l|}{ Length at birth ** $(\mathrm{cm})$} \\
\hline Epidemic period (case-control) & 90 & 42.84 & 3.97 & $<0.001$ \\
\hline Pre-epidemic period (cohort) & 25 & 46.16 & 1.97 & \\
\hline \multicolumn{5}{|l|}{ Head circumference at birth $(\mathrm{cm})$} \\
\hline Epidemic period (case-control) & 91 & 29.47 & 2.70 & $<0.001$ \\
\hline Pre-epidemic period (cohort) & 25 & 31.67 & 0.92 & \\
\hline \multicolumn{5}{|l|}{ Birth weight (z-score) } \\
\hline Epidemic period (case-control) & 91 & -2.72 & 0.10 & 0.241 \\
\hline Pre-epidemic period (cohort) & 25 & -2.42 & 0.13 & \\
\hline \multicolumn{5}{|l|}{ Length at birth ** (z-score) } \\
\hline Epidemic period (case-control) & 90 & -2.60 & 0.11 & 0.056 \\
\hline Pre-epidemic period (cohort) & 25 & -2.17 & 0.13 & \\
\hline \multicolumn{5}{|l|}{ Head circumference at birth (z-score) } \\
\hline Epidemic period (case-control) & 91 & -2.79 & 1.15 & 0.041 \\
\hline Pre-epidemic period (cohort) & 25 & -2.35 & 0.35 & \\
\hline
\end{tabular}

SD: standard deviation.

* Mann-Whitney U-test;

** Length was unavailable for 1 child $(n=115)$.

In the postnatal period, we also observed the brain lesions and the lower growth rate of the head circumference of neonates exposed to the Zika virus 23,24 . Thus, in order to determine whether reduction in linear growth is secondary to brain damage affecting the physiology of growth or to anatomical impairment of the head, we suggest that future studies evaluate the linear growth of these neonates by analyzing the body, torso, lower limbs and segments of the head separately.

The frequency of neonates exposed and not exposed to the Zika virus epidemic did not differ concerning the body proportionalities between weight, length, and head circumference, and we observed that $52 \%$ of the neonates with altered brain imaging were proportionate. Therefore, in a microcephaly epidemic condition due to exposure to congenital Zika virus infection, being born with low weight and body proportionality does not exclude microcephaly due to congenital infection, nor does it exclude the diagnosis of brain lesion, and longitudinal follow-up is also necessary for these children.

According to the criterion of Dine et al. 10, we observed a higher number of disproportionate neonates among the group of neonates with microcephaly born during the epidemic period; similarly, we also observed that only one child of the pre-epidemic period presented a disproportion of head circumference/length according to this criterion. That is, even with microcephaly, the neonates born during the pre-epidemic period presented a higher ratio between the head circumference and the length. Therefore, we consider that body differences exist between neonates with microcephaly exposed and not exposed to this virus. This finding is reinforced when we observe that the frequency of neonates with laboratory confirmation of Zika virus infection and the brain alterations was higher among disproportionate neonates considering the criterion of Dine et al. 10, which suggests that being disproportionate may be related to the severity of microcephaly due to exposure to the virus. However, even in proportionate neonates according to this criterion, $67 \%$ had altered brain imaging; thus, a specialized clinical follow-up is also suggested for these neonates. 
Table 5

Body weight, length, and proportionality at birth, according to brain imaging data of neonates with microcephaly from the epidemic period. State of Pernambuco, Brazil (2016).

\begin{tabular}{|c|c|c|c|c|c|c|}
\hline \multirow[t]{3}{*}{ Anthropometric characteristics } & \multicolumn{5}{|c|}{ Brain imaging in neonates with microcephaly * } & \multirow[t]{3}{*}{ p-value ** } \\
\hline & \multirow[t]{2}{*}{$\mathbf{N}=79$} & \multicolumn{2}{|c|}{ Altered } & \multicolumn{2}{|c|}{ Normal } & \\
\hline & & $\mathbf{N}=\mathbf{2 1}$ & $\%$ & $\mathbf{N}=\mathbf{5 8}$ & $\%$ & \\
\hline \multicolumn{7}{|l|}{ Birth weight (g) } \\
\hline$\geq 2,500$ & 20 & 8 & 38.1 & 12 & 20.7 & 0.102 \\
\hline$<2,500$ & 59 & 13 & 61.9 & 46 & 79.3 & \\
\hline \multicolumn{7}{|l|}{ Birth weight/Gestational age (SD) } \\
\hline$<-2$ & 54 & 12 & 57.1 & 42 & 72.4 & 0.155 \\
\hline$\geq-2$ & 25 & 9 & 42.9 & 16 & 27.6 & \\
\hline \multicolumn{7}{|l|}{ Length at birth/Gestational age (SD) } \\
\hline$<-2$ & 56 & 13 & 61.9 & 43 & 74.1 & 0.217 \\
\hline$\geq-2$ & 23 & 8 & 38.1 & 15 & 25.8 & \\
\hline \multicolumn{7}{|l|}{ Body proportionality (z-score) } \\
\hline Disproportionate & 34 & 10 & 47.6 & 24 & 41.4 & 0.404 \\
\hline Proportionate & 45 & 11 & 52.4 & 34 & 58.6 & \\
\hline \multicolumn{7}{|l|}{ Body proportionality *** } \\
\hline Disproportionate & 11 & 7 & 33.3 & 4 & 6.7 & 0.006 \\
\hline Proportionate & 68 & 14 & 66.9 & 54 & 93.1 & \\
\hline
\end{tabular}

SD: standard deviation.

* $\mathrm{N}=12$ neonates with no imaging results;

** Pearson's chi-square; Fisher's exact test;

$\star \star \star$ Proportionality criterion according to Dine et al. 10.

We emphasize that, before this study, different cut-off points for head circumference and body disproportionality were used as parameters to classify microcephaly due to congenital Zika virus infection, and microcephaly accompanied by low weight and proportionate body at birth were sometimes not considered cases of microcephaly because the neonates were small and proportional at birth. Few studies conducted an in-depth investigation of the relationship between anthropometric parameters, laboratory positivity for Zika virus and presence of brain abnormalities in infants. Our results contribute to improving the screening of microcephaly related to Zika virus infection, especially in developing countries, including health practitioners, policy makers and health service administrators.

As limitations we point out that the study design was limited to information in the databases of historical cohort and case-control studies not designed for this purpose. Although only newborns without clinical signs of congenital infections were enrolled in the retrospective cohort study, the fact that they were not collected images of computerized tomography limited the confirmation of this information. Since historical control was not concurrently recruited with the cases of microcephaly related to Zika virus congenital infection, using data set from previous studies are prone to introduce bias in the analysis and in the interpretation of the results. However, for the comparison between characteristics of neonates with microcephaly related to Zika virus, this historical control group seems to be adequate and a feasible choice. Furthermore, this historical data set derives from a welldesigned study with standardized anthropometric measures in the same state. Nevertheless, we cannot exclude the potential bias considering the socioeconomic conditions of the pregnant women and the adverse neonates' outcomes since comparison data was obtained with a lag time of two decades. We observed no bias effect introduced by the chosen historical control when analyzing that microcephaly was more severe during Zika outbreak compared with previous data from historical control. 
Table 6

Body weight, length, and proportionality according to laboratory evidence for Zika virus in neonates with microcephaly from the epidemic period. State of Pernambuco, Brazil (2016).

\begin{tabular}{|c|c|c|c|c|c|c|}
\hline \multirow[t]{3}{*}{ Anthropometric characteristics } & \multicolumn{5}{|c|}{ Laboratory evidence for Zika virus } & \multirow[t]{3}{*}{ p-value * } \\
\hline & \multirow[t]{2}{*}{$N=91$} & \multicolumn{2}{|c|}{ Positive } & \multicolumn{2}{|c|}{ Negative } & \\
\hline & & $\mathbf{N}=32$ & $\%$ & $\mathbf{N}=\mathbf{5 9}$ & $\%$ & \\
\hline \multicolumn{7}{|l|}{ Birth weight (g) } \\
\hline$\geq 2,500$ & 70 & 23 & 71.9 & 47 & 79.7 & 0.278 \\
\hline$<2,500$ & 21 & 9 & 28.1 & 12 & 20.3 & \\
\hline \multicolumn{7}{|l|}{ Birth weight/Gestational age (SD) } \\
\hline$<-2$ & 61 & 21 & 65.6 & 40 & 67.8 & 0.506 \\
\hline$\geq-2$ & 30 & 11 & 34.4 & 19 & 32.2 & \\
\hline \multicolumn{7}{|c|}{ Length at birth $* * /$ Gestational age (SD) } \\
\hline$<-2$ & 61 & 21 & 65.6 & 40 & 69.0 & 0.461 \\
\hline$\geq-2$ & 29 & 11 & 34.4 & 18 & 31.0 & \\
\hline \multicolumn{7}{|l|}{ Body proportionality (z-score) } \\
\hline Disproportionate & 41 & 14 & 43.7 & 27 & 45.8 & 0.515 \\
\hline Proportionate & 50 & 18 & 56.2 & 32 & 54.2 & \\
\hline \multicolumn{7}{|l|}{ Body proportionality *** } \\
\hline Disproportionate & 17 & 10 & 31.2 & 7 & 12.1 & 0.028 \\
\hline Proportionate & 73 & 22 & 68.8 & 51 & 87.9 & \\
\hline
\end{tabular}

SD: standard deviation.

* Pearson's chi-square; Fisher's exact test:

** Length at birth was unavailable for 1 child $(n=90)$;

*** Proportionality criterion according to Dine et al. 10.

In conclusion, microcephaly as a phenotype of congenital Zika syndrome is more severe than microcephaly in neonates born previously to the Zika virus epidemic in Brazil. We also observed an impairment of linear growth in neonates with microcephaly due to congenital Zika virus infection, as well as that the presence of low birth weight does not differ between neonates with microcephaly exposed or not to the virus, and that the disproportion between head circumference and length can be an indicator of severity of microcephaly due to exposure to the Zika virus. 


\section{Contributors}

F. C. L. S. P. Gonçalves conceived and designed the study, analyzed and interpreted the data, and drafted the manuscript. M. C. Lima and T. V. B. Araújo conceived and designed the study and drafted the manuscript. R. A. A. Ximenes conceived and designed the study and analyzed and interpreted the data. D. B. Miranda-Filho, C. M. T. Martelli, L. C. Rodrigues, and S. H. Eickmann critically revised the manuscript. W. V. Souza and P. I. C. Lira analyzed and interpreted the data. All authors aproved the final version of the manuscript.

\section{Additional informations}

ORCID: Fabiana Cristina Lima da Silva Pastich Gonçalves (0000-0002-0275-6392); Marília de Carvalho Lima (0000-0002-4993-2584); Ricardo Arraes de Alencar Ximenes (0000-0002-99518840); Demócrito de Barros Miranda-Filho (00000003-2537-1476); Celina Maria Turchi Martelli (0000-0002-2491-0688); Laura Cunha Rodrigues (0000-0001-9008-660X); Wayner Vieira de Souza (0000-0002-0939-9332); Pedro Israel Cabral de Lira (0000-0002-1534-1620); Sophie Helena Eickmann (0000-0002-6523-2107); Thalia Velho Barreto Araújo (0000-0001-9956-4145).

\section{Acknowledgments}

We are grateful to the funding institutions, the University of Pernambuco, the Federal University of Pernambuco, the London School of Hygiene \& Tropical Medicine, the Fiocruz Pernambuco, and the Brazilian National Research Council (CNPq) for providing research grants to M.C.L., R.A.A.X., C.M.T.M., W.V.S. and P.I.C.L. We thank the director and staff of the participating hospitals and the mothers for their collaboration and generosity.

\section{References}

1. Araújo TVB, Ximenes RAA, Miranda-Filho DB, Souza WV, Montarroyos UR, Melo APL, et al. Association between microcephaly with Zika virus infection, and other risk factors in Brazil: final report of a case-control study. Lancet Infect Dis 2018; 18:328-36.

2. Moore CA, Staples JE, Dobyns WB, Pessoa A, Ventura CV, Fonseca EB, et al. Characterizing the pattern of anomalies in congenital Zika syndrome for pediatric clinicians. JAMA Pediatr 2016; 171:288-95.

3. Miranda-Filho DB, Martelli CM, Ximenes RA, Araújo TV, Rocha MA, Ramos RC, et al. Initial description of the presumed congenital Zika syndrome. Am J Public Health 2016; 106:598-600.

4. Secretaria de Vigilância em Saúde/Secretaria de Atenção à Saúde, Ministério da Saúde. Orientações integradas de vigilância e atenção à saúde no âmbito da Emergência de Saúde Pública de Importância Nacional. Procedimentos para o monitoramento das alterações no crescimento e desenvolvimento a partir da gestação até a primeira infância, relacionadas à infecção pelo vírus Zika e outras etiologias infeciosas dentro da capacidade operacional do SUS. Brasília: Ministério da Saúde; 2017.

5. Kaur H, Bhalla AK, Kumar P. Longitudinal growth of head circumference in term symmetric and asymmetric small for gestational age infants. Early Human Dev 2012; 88:473-8.

6. Hutcheon JA, Jacobsen GW, Kramer MS, Martinussen M, Platt RW. Small size at birth or abnormal intrauterine growth trajectory: which matters more for child growth? Am J Epidemiol 2016; 183:1107-13.

7. von der Hagen M, Pivarcsi M, Liebe J, von Bernuth H, Didonato N, Hennermann JB, et al. Diagnostic approach to microcephaly in childhood: a two-center study and review of the literature. Dev Med Child Neurol 2014; 56:732-41.

8. Krow-Lucal ER, Andrade MR, Cananéa JNA, Moore CA, Leite PL, Biggerstaff BJ, et al. Association and birth prevalence of microcephaly attributable to Zika virus infection among infants in Paraíba, Brazil, in 2015-2016: a casecontrol study. Lancet Child Adolesc Health 2018; 2:205-13.

9. Brasil P, Pereira Jr. JP, Moreira ME, Ribeiro Nogueira RM, Damasceno L, Wakimoto M, et al. Zika virus infection in pregnant women in Rio de Janeiro. N Engl J Med 2016; 375:2321-34.

10. Dine MS, Gartside PS, Glueck CJ, Rhein L, Greene G, Khoury P. Relationship of head circumference to length in the first 400 days of life: a mnemonic. Pediatrics 1981; 67:506-7.

11. Brasil P, Nielsen-Saines K. More pieces to microcephaly-Zika puzzle in Brazil. Lancet Infect Dis 2016; 16:1307-9.

12. Lima M, Ismail S, Ashworth A, Morris SS. Influence of heavy agricultural work during pregnancy on birthweight in Northeast Brazil. Int J Epidemiol 1999; 28:469-74. 
13. Capurro H, Korichzky S, Fonseca O, CaldeiroBarcia R. A simplified method for diagnosis of gestational age in the newborn infant. J Pediatr 1978; 93:120-2.

14. Fenton TR, Kim JH. A systematic review and meta-analysis to revise the Fenton growth chart for preterm infants. BMC Pediatr 2013;13: 59-72.

15. Villar J, Cheikh Ismail L, Victora CG, Ohuma EO, Bertino E, Altman DG, et al. International standards for newborn weight, length, and head circumference by gestational age and sex: the Newborn Cross-Sectional Study of the INTERGROWTH-21st Project. Lancet 2014; 384:857-68

16. World Health Organization. WHO Child Growth Standards: head circumference-forage, arm circumference-for-age, triceps skinfold-for-age and subscapular skinfold-for-age. Methods and development. Geneva: World Health Organization; 2007.

17. United Nations Children's Fund; World Health Organization. Low birthweight: country, regional and global estimates. New York: United Nations Children's Fund; 2004.

18. Murphy VE, Smith R, Giles WB, Clifton VL. Endocrine regulation of human fetal growth: the role of the mother, placenta, and fetus. Endocr Rev 2006; 27:141-69.

19. Godfrey KM, Haugen G, Kiserud T, Inskip HM, Cooper C, Harvey NC, et al. Fetal liver blood flow distribution: role in human developmental strategy to prioritize fat deposition versus brain development. PLoS One 2012; $7:$ e41759.
20. Kiserud T. Physiology of the fetal circulation. Semin Fetal Neonatal Med 2005; 10:493-503.

21. Kramer MS, McLean FH, Olivier M, Willis DM, Usher RH. Body proportionality and head and length 'sparing' in growth-retarded neonates: a critical reappraisal. Pediatrics 1989; 84:717-23.

22. Driggers RW, Ho CH, Korhonen EM, Kuivanen S, Jääskeläinen AJ, Smura T, et al. Zika virus infection with prolonged maternal viremia and fetal brain abnormalities. N Engl J Med 2016; 374:2142-51.

23. van der Linden V, Pessoa A, Dobyns W, Barkovich AJ, van der Linden Júnior $H$, Rolim Filho EL, et al. Description of 13 infants born during october 2015-january 2016 with congenital Zika virus infection without microcephaly at birth - Brazil. MMWR Morb Mortal Wkly Rep 2016; 65:1343-8.

24. Moura da Silva AA, Ganz JS, Sousa PD, Doriqui MJ, Ribeiro MR, Branco MD, et al. Early growth and neurologic outcomes of infants with probable congenital Zika virus syndrome. Emerg Infect Dis 2016; 22:1953-6. 


\section{Resumo}

O estudo buscou comparar as medidas antropométricas e proporções corporais de recém-nascidos do período pré-Zika com os nascidos durante a epidemia de microcefalia congênita pelo vírus Zika. Comparamos 958 recém-nascidos do período préZika com 264 nascidos durante o período epidêmico. Foram classificados o perímetro cefálico, peso e comprimento dos neonatos de acordo com a escala de crescimento de Fenton es Kim. Consideramos desproporcionais aqueles neonatos que apresentaram microcefalia e peso ou comprimento adequado para sexo e idade gestacional, além daqueles cujo perímetros cefálicos eram menores que a razão ((comprimento / 2) +9,5)-2,5cm. Estimamos as frequências de positividade para Zika e resultados de imagens de cerebrais entre bebês com microcefalia nascidos no período epidêmico, em relação aos parâmetros antropométricos e de proporcionalidade corporal. Baixo peso e microcefalia proporcional foram semelhantes entre recém-nascidos de ambos os periodos. Entretanto, as frequências de neonatos com microcefalia e com comprimento muito curto e microcefalia desproporcional foram muito maiores entre os nascidos no período epidêmico com anomalias cerebrais e positivos para Zika. Concluímos que a desproporção entre perímetro cefálico e comprimento ao nascer pode ser um indicador da gravidade da microcefalia causada pela síndrome congênita do Zika vírus.

Microcefalia; Síndrome Congênita de Zika; Peso ao Nascer

\section{Resumen}

El objetivo del estudio fue comparar las medidas antropométricas $y$ de proporcionalidad corporal en neonatos nacidos durante un periodo pre-Zika, con quienes nacieron durante la epidemia de microcefalia por el síndrome congénito Zika. Comparamos a 958 neonatos nacidos durante la epidemia pre-Zika, con 264 neonatos nacidos durante el período epidémico. A los recién nacidos se les clasificó su circunferencia de la cabeza, peso y longitud según la tabla de crecimiento Fenton ro Kim. Consideramos desproporcionados a quienes presentaron microcefalia y peso o longitud adecuada para sexo y edad gestacional, y quienes tenian unas circunferencias de cabeza cuyo ratio era menor que $(($ longitud / 2) + 9.5) - 2.5cm. Estimamos las frecuencias de positividad para Zika, así como los resultados de imágenes cerebrales entre neonatos nacidos con microcefalia durante el período epidémico, en relación con parámetros antropométricos y de proporcionalidad corporal. Bajo peso $y$ microcefalia proporcional fueron similares entre los recién nacidos de ambos períodos. No obstante, las frecuencias de recién nacidos con microcefalia con una longitud muy baja y microcefalia desproporcionada fueron mayores entre los neonatos del período epidémico, con anormalidades cerebrales $y$ positivos para Zika. Concluimos que la desproporción entre la circunferencia de cabeza y longitud al nacer puede ser un indicador de la gravedad de la microcefalia, causada por el Zika congénito.

Microcefalia; Sindrome Congénito por el Virus del Zika; Peso al Nacer
Submitted on 31/Aug/2020

Final version resubmitted on 27/Jan/2021

Approved on 26/Feb/2021 